\title{
Nawracający płyn w jamie opłucnej u chorego z niewydolnością serca z obniżoną frakcją wyrzutową lewej komory
}

\section{Recurrent fluid in the pleural cavity in patient with chronic heart failure with reduced left ventricular ejection fraction}

\author{
Alicja M. Jarząbek \\ I Oddział Chorób Wewnętrznych Szpitala Wolskiego im. dr Anny Gostyńskiej w Warszawie
}

\section{Streszczenie}

Mężczyzna w wieku 69 lat został przyjęty na oddział z powodu objawów zaostrzenia przewlekłej niewydolności serca do IV klasy według New York Heart Association. Wykonane badania, w tym zdjęcie radiologiczne klatki piersiowej, wykazały obecność płynu, który wypełniał niemal całą prawą jamę opłucnej. Płyn uznano za przyczynę zgłaszanych dolegliwości. Z powodu szybkiego narastania poziomu płynu o charakterze wysiękowym w jamie opłucnej, wymagającego wielokrotnych punkcji w ciągu kilku miesięcy, oraz braku cech zaostrzenia niewydolności serca wykonano pełną diagnostykę pulmonologiczną, która początkowo nie wykazała nieprawidłowości. Jednak po powtórnym wykonaniu badań rozpoznano raka gruczołowego płuca prawego. Pacjent jest obecnie kwalifikowany do leczenia onkologicznego.

Słowa kluczowe: przewlekła niewydolność serca, płyn opłucnowy, rak gruczołowy płuc

Folia Cardiologica 2018; 13, 3: 252-255

\section{Wstęp}

W ostatnich latach gwałtownie wzrosła częstość występowania raka płuca i umieralność na tę chorobę. To spowodowało, że stał się on najczęstszym śmiertelnym rakiem u kobiet i mężczyzn [1]. Największym czynnikiem ryzyka raka płuca jest palenie tytoniu, ale wpływ na jego rozwój mają także wiek, zanieczyszczenie środowiska, ekspozycja zawodowa, płeć, rasa, a także czynniki genetyczne [2]. Około $25 \%$ nowotworów płuca nie wynika z palenia tytoniu [3].

Jednym z typów histopatologicznych nowotworów płuca jest rak gruczołowy, który w swoim przebiegu klinicznym różni się od pozostałych raków płuc z grupy niedrobnokomórkowych. Najczęściej rozwija się w obwodowych partiach płuc, nie dając typowych objawów z dróg oddechowych. Już na wczesnym etapie dochodzi do przerzutów drogą krwiopochodną, najczęściej do mózgu $[4,5]$.

W niniejszej pracy przedstawiono przypadek pacjenta w wieku 69 lat z przewlekłą niewydolnością serca, nigdy niepalącego tytoniu, z nawracającym płynem w jamie opłucnej sugerującym nawrotowe zaostrzenia choroby podstawowej. Objawy okazały się jednak podstępnie rozwijającym się procesem rozrostowym płuca prawego.

\section{Opis przypadku}

Mężczyzna w wieku 69 lat z przewlekłą niewydolnością serca klasy II według New York Heart Association (NYHA) 
wezwał pogotowie z powodu silnej duszności oraz bólu w klatce piersiowej z uczuciem kołatania serca. W wywiadzie pacjent podał stabilną chorobę wieńcową o nasileniu II w skali według Canadian Cardiovascular Society (CCS), stan po zawale serca w 1993 roku leczonym zachowawczo, stan po pomostowaniu aortalno-wieńcowym: aorty i tętnicy zstępującej przedniej (Ao-LAD, aorta-left anterior descending), Ao i gałęzi marginalnej (Ao-OM, aorta-obtuse marginal branch), Ao i tylnej gałęzi zstępującej (Ao-PDA, aorta-posterior descending artery) w 1999 roku, przebyty zawał serca bez uniesienia odcinka ST (NSTEMI, non-ST-segment elevation myocardial infarction) z nieskuteczną angioplastyką pomostu Ao-LAD powikłaną zatrzymaniem krążenia w 2013 roku oraz następczą implantacją jednojamowego kardiowertera-defibrylatora. U pacjenta wykonano także ablacje komorowych zaburzeń rytmu serca w 2016 roku. Leczony metforminą i pochodną sulfonylomocznika z powodu cukrzycy typu 2 źle kontrolowanej metaboliczniestężenie hemoglobiny glikowanej wynosiło 7,3\%. Pacjent od ostatniego incydentu wieńcowego nie wymagał hospitalizacji z powodu dekompensacji niewydolności serca. Nigdy nie palił tytoniu. Wywiad rodzinny nowotworowy: matka zmarła na raka piersi, córka chorowała na chłoniaka Hodgkina.

Pacjent przy przyjęciu był w stanie średnim, stabilnym, z dusznością spoczynkową. W badaniu przedmiotowym nie stwierdzono obrzęków obwodowych, wodobrzusza. Jedynie zaobserwowano ściszenie szmeru pęcherzykowego do III żebra po prawej stronie oraz tachykardię do 110/min. Ciśnienie tętnicze pozostawało w normie.

W badaniach laboratoryjnych (tab. 1) nie stwierdzono cech stanu zapalnego, enzymy wątrobowe i parametry nerkowe oraz stężenie elektrolitów w normie. Zwróciły uwagę: prawidłowe stężenie troponiny, nieznacznie podwyższony peptyd natriuretyczny typu B (pro-BNP, pro-B-type natriuretic peptide) nieadekwatnie do obrazu klinicznego sugerującego zaostrzenie przewlekłej niewydolności serca. W badaniu radiologicznym klatki piersiowej (ryc. 1) opisano płyn w prawej jamie opłucnowej sięgający III żebra, zagęszczenia miąższowe okolicy wnęki prawej, powiększoną sylwetkę serca. Podczas pobytu wykonano drenaż jam opłucnowych. Z prawej jamy opłucnej ewakuowano 4,5 litra płynu oraz z lewej - $300 \mathrm{ml}$ (ryc. 2). Płynu nie badano. Nie wykonano także badania echokardiograficznego podczas tego pobytu.

Z powodu nawrotowych dolegliwości związanych z gromadzeniem się płynu w jamie opłucnej, które wymagały wielokrotnych punkcji w ciągu kolejnych dwóch miesięcy, chorego skierowano na diagnostykę pulmonologiczną, która początkowo nie wykazała nieprawidłowości w obrazie płuc i oskrzeli poza nawrotowym płynem. Po miesiącu powtórnie wykonano badania i dokończono diagnostykę kardiologiczną (badanie echokardiograficzne). Opisano w nim ciężką dysfunkcję skurczową lewej komory, zachowaną funkcję
Tabela 1. Wyniki badań opisanego chorego

\begin{tabular}{|c|c|c|}
\hline Parametr & Wartość & Zakres normy \\
\hline Stężenie hemoglobiny [g/dl] & 12,4 & $14-18$ \\
\hline Liczba erytrocytów $\left[\times 10^{6} / \mu \mathrm{l}\right]$ & 4,23 & $4,5-5,9$ \\
\hline Wartość hematokrytu (\%) & 38,1 & $41-53$ \\
\hline Liczba leukocytów [× $\left.10^{3} / \mu \mathrm{l}\right]$ & 5,48 & $4,1-10,9$ \\
\hline Liczba płytek krwi $\left[\times 10^{3} / \mu l\right]$ & 176 & $150-400$ \\
\hline Stężenie kreatyniny [mg/dl] & 0,80 & $0,7-1,2$ \\
\hline Wartość GFR [ml/min] & 95,8 & $>60$ \\
\hline $\begin{array}{l}\text { Wartość hemoglobiny } \\
\text { glikowanej (\%) }\end{array}$ & 7,3 & $4,8-5,9$ \\
\hline Stężenie glukozy [mg/dl] & 120 & $70-99$ \\
\hline Stężenie CRP [mg/dl] & 0,66 & $<0,5$ \\
\hline Stężenie NT-proBNP [pg/ml] & 304 & $<125$ \\
\hline Stężenie troponiny T [ng/ml] & 0,023 & $<0,010$ \\
\hline Stężenie TSH [ $\mu \mathrm{jm} . / \mathrm{ml}]$ & 1,52 & $0,27-4,2$ \\
\hline Wartość AIAT [j./l] & 33 & $10-50$ \\
\hline Wartość AspAT [j./l] & 24 & $10-50$ \\
\hline Stężenie sodu [mmol/l] & 140 & $136-145$ \\
\hline Stężenie potasu [mmol/l] & 3,96 & $3,5-5,1$ \\
\hline \multicolumn{3}{|c|}{$\begin{array}{l}\text { GFR (glomerular filtration rate) - współczynnik przesaczania kłębuszkowego; CRP (C-reactive } \\
\text { protein) - białke C-reakttywne; NT-proBNP (N-terminal pro B-type natriuretic peptide) - N-końcowy } \\
\text { fragment propeptydu natriuretycznego typu B; TSH (thyroid-stimulating hormone) - hormon } \\
\text { tarczycy; AlAT (alanine aminotransferase) - aminotransferaza alaninowa; AspAT (aspartate amino } \\
\text { transferase) - aminotransferaza asparaginianowa }\end{array}$} \\
\hline
\end{tabular}

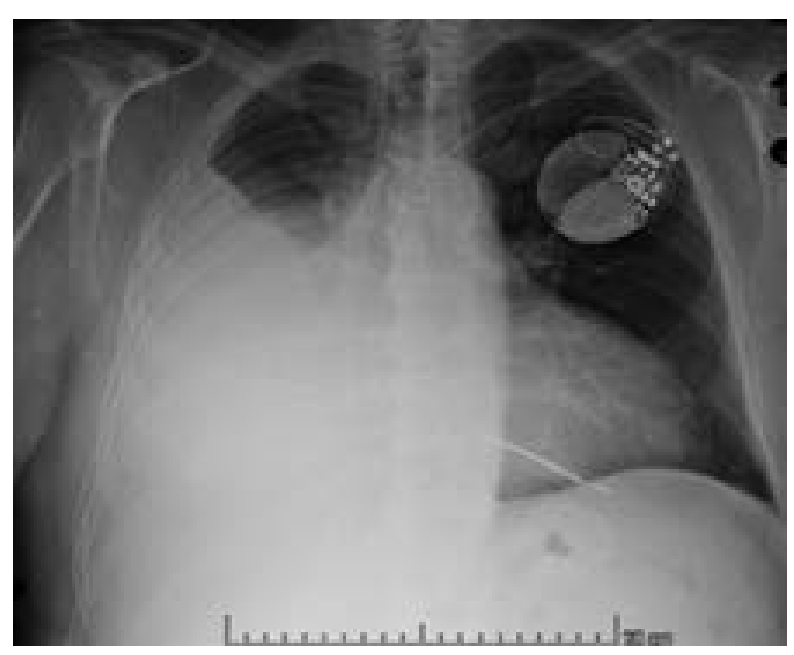

Rycina 1. Zdjęcie radiologiczne klatki piersiowej z płynem w prawej jamie opłucnej

skurczową prawej komory, powiększone oba przedsionki. Grubość ścian lewej komory była prawidłowa, frakcja wyrzutowa lewej komory (LVEF, left ventricular ejection fraction) wynosiła 20-25\%, stwierdzono łagodną niedomykalność zastawki aorty i tętnicy płucnej. Przeprowadzono pełną 


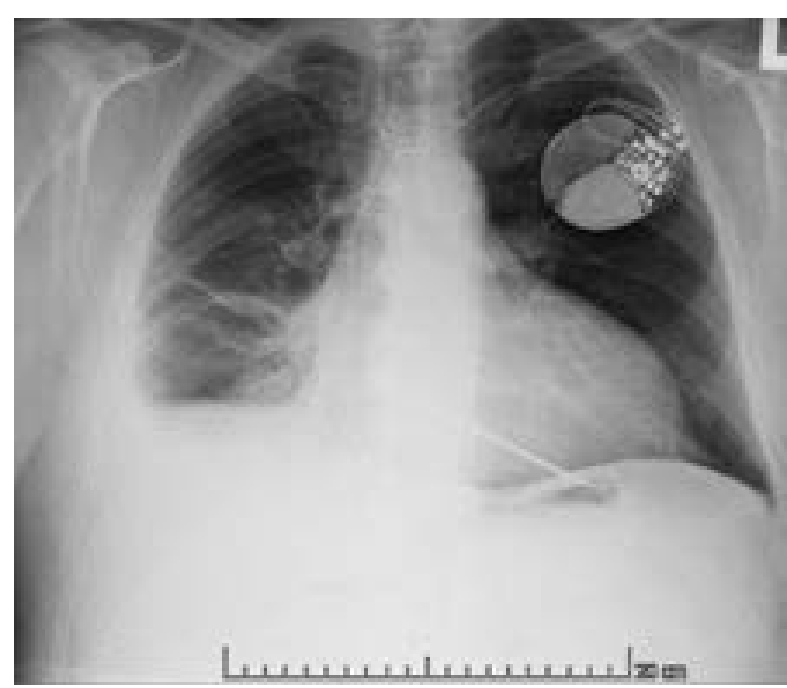

Rycina 2. Zdjęcie radiologiczne klatki piersiowej po drenażu prawej jamy opłucnej

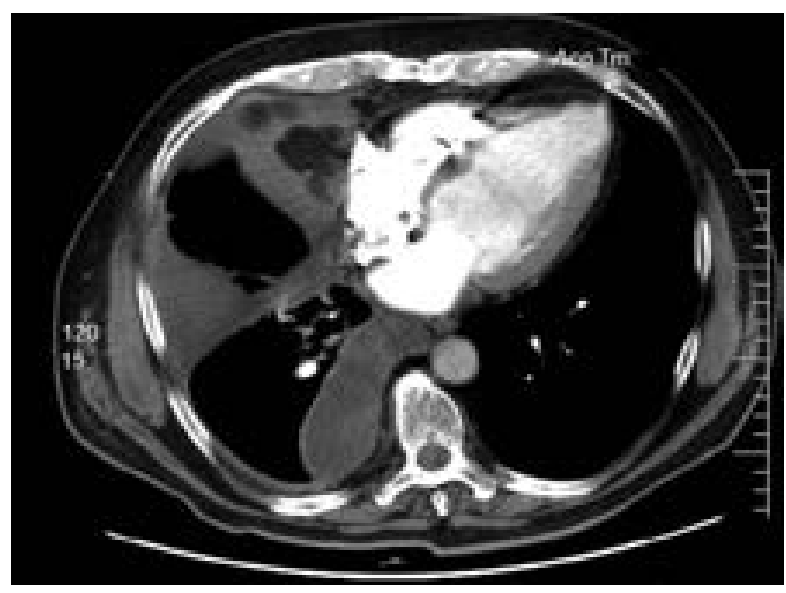

Rycina 3. Tomografia komputerowa klatki piersiowej z otorbionym płynem w prawej jamie opłucnej

diagnostykę płuc i oskrzeli. Płyn miał charakter wysiękowy według kryteriów Lighta (wskaźnik białkowy i dehydrogenaza mleczanowa, odpowiednio, 0,78 i 0,95). Wykluczono gruźlice i czynny stan zapalny. W spirometrii uwidoczniono zmiany restrykcyjne wynikające z otyłości (wskaźnik masy ciała [BMI, body mass index] 31,3 kg/m²), niewydolności krążenia i obecności płynu. W tomografii komputerowej (CT, computed tomography) klatki piersiowej stwierdzono obecność płynu w prawej jamie opłucnej z tendencją do otorbiania (ryc. 3), wskazującą na przyczynę krążeniową.
Jednak ze względu na zmiany miąższowe płuca prawego, pogrubienie ścian oskrzeli oraz powiększony węzeł chłonny przytchawiczy prawy (o wielkości $14 \mathrm{~mm}$ ) nie można było jednoznacznie wykluczyć procesu rozrostowego. Zdecydowano się zatem na wykonanie badania pozytonowej tomografii emisyjnej z tomografią komputerową (PET-CT, positron emission tomography-computed tomography). Uwidoczniono w nim masę miękkotkankową okolicy wnęki płuca prawego oraz liczne zgrubienia opłucnej ściennej o wysokim ryzyku aktywnego procesu rozrostowego. W toku weryfikacji histopatologicznej w pobranym materiale operacyjnym płuca i opłucnej rozpoznano raka gruczołowego płuca prawego. Pacjent obecnie jest kwalifikowany do leczenia onkologicznego.

\section{Omówienie}

Przedstawiony przypadek chorego przypomina, że każdego chorego, niezależnie od charakteru zgłaszanych dolegliwości, należy traktować interdyscyplinarnie, a diagnostykę planować i realizować wielokierunkowo. Zgłaszane przez pacjenta dolegliwości i brak obrzęków obwodowych sugerowały zaostrzenie lewokomorowej niewydolności serca. Jednak charakter płynu, który dotyczył głównie prawej jamy opłucnej, oraz stabilny obraz niewydolności serca (stabilne stężenia N-końcowego fragmentu propeptydu natriuretycznego typu B [NT-proBNP, N-terminal pro-B-type natriuretic peptide] i troponiny oraz obraz w echokardiografii porównywalny z obrazami z poprzednich badań) skłoniły do pogłębienia diagnostyki mimo prawidłowego obrazu w bronchoskopii i niejednoznacznych obrazów w CT klatki piersiowej. Wnikliwa diagnostyka i obserwacja ujawniły toczący się proces rozrostowy prawego płuca u pacjenta bez żadnych objawów sugerujących chorobę (kaszel, krwioplucie, zmniejszenie masy ciała).

Gromadzący się płyn wysiękowy w jamie opłucnej należało różnicować z gruźlicą, aktywnym stanem zapalnym oraz nowotworem. Wykluczenie wymienionych chorób w początkowym etapie diagnostyki różnicowej nie uśpiło czujności lekarzy. Pamiętali oni, że wśród chorych powyżej 50. roku życia u 37-73\% nowotwory to główna przyczyna wysięku opłucnowego [6], który świadczy zazwyczaj o znacznym zaawansowaniu choroby oraz niekorzystnym rokowaniu. Badanie PET-CT okazało się w tym przypadku niezbędne do szybkiego rozpoznania nowotworu [7].

\section{Konflikt interesów}

Autorka nie zgłasza konfliktu interesów. 


\section{Abstract}

A 69-year-old man was admitted to hospital due to symptoms of exacerbation of chronic heart failure to New York Heart Association class IV. Executed tests and chest X-ray presented fluid, which filled almost all right pleural cavity. We recognised, that it was the reason of his complaints. Because of the fact, that the level of exudative fluid in the pleural cavity was recurrent, the patient required multiple punctures during few months. On the other hand, the patient did not present any features of exacerbation of heart failure. Therefore we decided to perform full pulmonological diagnostics. At the beginning, there were no abnormalities. However due to the further, more advanced tests we recognised adenocarcinoma of the right lung. The patient is qualified to oncological treatment.

Key words: chronic heart failure, pleural fluid, lung adenocarcinoma

Folia Cardiologica 2018; 13, 3: 252-255

\section{Piśmiennictwo}

1. Beckett WS. Epidemiology and etiology of lung cancer. Clin Chest Med. 1993; 14(1): 1-15, indexed in Pubmed: 8462243.

2. de Groot P, Munden RF. Lung cancer epidemiology, risk factors, and prevention. Radiol Clin North Am. 2012; 50(5): 863-876, doi: 10.1016/j.rcl.2012.06.006, indexed in Pubmed: 22974775.

3. Sun S, Schiller JH, Gazdar AF. Lung cancer in never smokers - a different disease. Nat Rev Cancer. 2007; 7(10): 778-790, doi: 10.1038/ /nrc2190, indexed in Pubmed: 17882278.

4. Huras B. Rak gruczołowy płuca w IV stadium zaawansowania rozpoznany u 47-letniej chorej - opis postępowania diagnostycznego. Onkol Prak Klin. 2014; 10(Suppl G): G6-G8.
5. Franklin WA. Diagnosis of lung cancer: pathology of invasive and preinvasive neoplasia. Chest. 2000; 117(Suppl 1): 80S-89S, indexed in Pubmed: 10777460.

6. Drozdowska A, Jassem E. Postępowanie w nawracających wysiękach opłucnowych w przebiegu chorób nowotworowych. Pol Med Paliatywna. 2003; 2(4): 227-233.

7. Opoka L, Szołkowska M, Podgajny Z, et al. [Staging of non-small cell lung cancer using CT and integrated PET-CT]. Pneumonol Alergol Pol. 2013; 81(1): 5-15, indexed in Pubmed: 23258466. 